\title{
PENGARUH PSIKOTERAPI POSITIF TERHADAP PENINGKATAN KESEJAHTERAAN SUBJEKTIF PADA WANITA DEWASA AWAL YANG BELUM MEMILIKI PASANGAN
}

\section{THE EFFECT OF POSITIVE PSYCHOTHERAPY TO IMPROVE SUBJECTIVE WELL- BEING OF EARLY ADULTHOOD WOMAN WHO HASN'T HAD A PARTNER}

\author{
Catur Pamungkas \\ Nurul Wardhani \\ Ahmad Gimmy Prathama Siswadi \\ Fakultas Psikologi Universitas Padjadjaran Bandung \\ Email: pamungkas1610@gmail.com; ahmad.gimmy@unpad.ac.id
}

\begin{abstract}
This study aims to determine the effect of positive psychotherapy on improving the welfare well-being of early adult women who do not have a partner/boy friend/fiancee. Positive psychotherapy (PPT) is a therapy developed by Tayyab Rashid using a positive psychological approach. The goal of this therapy is to build a pleasant life, engagement life, and a meaningful life, by optimizing the power side of a person and maximizing the usefulness of positive emotions. The researchs design in this research is quasi experimental, involving two Participants using purposive sampling technique. Data were obtained by using interview method, observation, and questionnaire. The questionnaire used in this research is Satisfaction with Life Scale (SWLS) and positive and negative influences affect schedule (PANAS). Positive psychotherapy is given as much as six sessions. Measurements are made twice, ie before and after the intervention. . Data were analyzed using descriptive-qualitative analysis. The results showed. Positive psychotherapy gives effect in improving subjective wellbeing of single early adult women who do not have a partner/boy friend/fiancee.
\end{abstract}

Keywords: positive psychotherapy, positive psychology, subjective well-being

\begin{abstract}
ABSTRAK
Penelitian ini bertujuan untuk mengetahui pengaruh psikoterapi positif terhadap peningkatan kesejahteraan subjektif wanita dewasa awal yang belum memiliki pasangan. Positive psychotherapy (PPT) adalah terapi yang dikembangkan oleh Tayyab Rashid (2013) dengan menggunakan pendekatan psikologi positif. Tujuan dari terapi ini adalah membangun pleasant life, engaged life, dan meaningfull life, dengan mengoptimalkan sisi kekuatan dari seseorang dan memaksimalkan kegunaan dari emosi positif. Rancangan dalam penelitian ini adalah eksperimental semu, dengan melibatkan dua partisipan penelitian yang diperoleh melalui teknik purposive sampling. Data diperoleh dengan menggunakan metode wawancara, observasi, dan kuesioner. Kuesioner yang digunakan adalah Satisfaction With Life Scale (SWLS) dan positive affect and negative affect schedule (PANAS). Psikoterapi positif diberikan sebanyak enam sesi. Pengukuran dilakukan sebanyak dua kali, yaitu sebelum dan setelah intervensi diberikan, serta dilakukan evaluasi secara kualitatif dari setiap proses sesi yang dilalui. Data dianalisis dengan menggunakan teknik statistika deskriptif dan kualitatif. Hasil penelitian menunjukkan bahwa Psikoterapi positif memberikan pengaruh dalam meningkatkan kesejahteraan subjektif wanita dewasa awal yang belum memiliki pasangan.
\end{abstract}

Kata Kunci: psikoterapi positif, psikologi positif, kesejahteraan subjektif 
Pada saat memasuki masa dewasa, individu menghadapi beberapa macam pilihan untuk melanjutkan kehidupannya. Umumnya pada masa ini, individu dewasa sudah menyelesaikan proses mengenyam pendidikan sampai pada strata sarjana. Individu dewasa awal kemudian akan dihadapkan pada beberapa pilihan jalan hidup yang akan segera ditempuh setelah menyelesaikan pendidikannya, salah satunya adalah menikah. Pada kenyataanya mengambil keputusan untuk menikah tidak sederhana dan dipengaruhi berbagai macam faktor yang berbeda pada masing-masing individu, misalnya kesiapan secara finansial, kesuksesan dalam proses penyesuaian dengan pasangan, kematangan secara emosi, dan faktor budaya.

Berdasarkan sudut padang psikologi perkembangan, menikah merupakan salah satu tugas perkembangan yang harus diselesaikan oleh individu masa dewasa. Kematangan secara seksual menimbulkan adanya keinginan untuk menjalin relasi yang lebih intim dengan lawan jenis, namun kondisi tersebut tidak serta-merta membuat individu, baik wanita maupun pria, memutuskan untuk menikah. Ambisi dalam pendidikan dan karir merupakan salah satu alasan yang membuat individu dewasa menunda pernikahannya. Di sisi lain, faktor budaya juga memberikan pengaruh terhadap isu pernikahan.
Lingkungan keluarga, khususnya pada budaya di Indonesia, memiliki harapan pada individu untuk segera mendapatkan pasangan dan menikah ketika sudah beranjak dewasa. Berdasarkan penelitian terdahulu, saat individu memasui dewasa awal terdapat peluang mengalami quarter life crisis, yaitu krisis usia seperempat abad yang bersumber dari penuntasan pendidikan, pencapaian pekerjaan dan pernikahan (Robinson, 2008). Saat krisis tersebut tidak dapat dihadapi secara adaptif individu berpeluang mengalami simtom-simtom negatif seperi stres atau depresi.

Data statistik menunjukkan bahwa rata-rata usia nikah pertama penduduk Indonesia pada tahun 2000 adalah 24 tahun. Penelitian lain terhadap wanita Indonesia kelompok usia 20-24 tahun mendapatkan fakta bahwa $56,2 \%$ di antara mereka sudah menikah (Riskesdas, 2010). Berdasarkan penelitian yang sama ditemukan juga pada wanita yang berasal dari perkotaan yang menikah di usia 2024 tahun sebesar 38,7\%, usia 25-29 sebesar $15,8 \%$. Berdasarkan latar belakang pendidikan, persentase wanita lulusan S1 yang menikah di usia 20-24 tahun sebesar $42,6 \%$, sedangkan prosentase wanita lulusan S1 yang menikah di usia 25-29 tahun sebesar 41,2\%.

Harapan dari lingkungan mengenai pernikahan umumnya berasal dari keluar- 
ga, tetangga, dan teman-teman. Saat individu memasuki usia dewasa, umumnya lingkungan sudah mulai mengajukan pertanyaan seputar relasi intim dengan lawan jenis, menanyakan kapan akan menikah, bahkan sampai bentuk menuntut untuk segera menikah. Harapan dari lingkungan, khususnya keluarga, untuk menikah tidak jarang ditanggapi sebagai sebuah tekanan, terutama pada wanita usia dewasa yang masih belum memiliki pasangan (calon suami). Sebuah studi terhadap 23 wanita suku Jawa menunjukkan bahwa harapan sosial memberikan kontribusi terhadap kondisi stres pada wanita lajang usia dewasa muda sebesar 23\% (Hanugraheni \& Nu'man, 2008).

Pernikahan merupakan salah satu faktor yang turut berperan pada tinggi atau rendahnya kesejahteraan subjektif (subjective well-being) seseorang. Dalam suatu survei besar ditunjukkan kebahagiaan yang lebih besar terletak pada orang-orang yang menikah dibandingkan dengan mereka yang belum menikah atau yang pernah menikah kemudian bercerai. Pernikahan berfungsi sebagai penyangga terhadap kesulitan hidup dan menyediakan dukungan emosi dan ekonomi yang menghasilkan kondisi positif pada well-being. Individu yang telah menikah secara konsisten menunjukkan kesejahteraan subjektif yang lebih tinggi dari yang tidak pernah menikah dan individu yang sebelumnya pernah menikah (berpisah)
(Glen dkk, dalam Oishi, 1998). Gove dan Umberson (Oishi, 1998) menunjukkan bahwa pernikahan memberikan arti positif yang kuat dari identitas dan harga diri. Williams (Oishi, 1998) menyimpulkan bahwa keintiman antar pribadi dan dukungan emosional yang diberikan oleh pasangan menciptakan kesejahteraan.

Pernikahan merupakan salah satu faktor yang menentukan tinggi atau rendahnya kesejahteraan subjektif seseorang. Namun, perlu diperhatikan bahwa individu yang belum atau tidak menikah bukan berarti mengalami kesejahteraan subjektif yang rendah. Kesejahteraan subjektif merupakan evaluasi kognitif dan afektif seseorang atas hidupnya. Evaluasi ini meliputi reaksi emosional terhadap suatu peristiwa dan penilaian secara kognitif kepuasan terhadap hidupnya. Hal tersebut menunjukkan bahwa individu memiliki standar masing-masing (subjective) untuk bahagia atau sejahtera. Pendekatan goal theory terhadap kesejahteraan subjektif menjelaskan bahwa individu mencapai kesejahteraan subjektif ketika mereka bergerak mendekati atau bahkan mencapai sebuah kondisi ideal yang berharga menurut dirinya. Pada permasalahan tentang pernikahan pun demikian, ketika individu memiliki tujuan untuk segera menikah, maka kondisi melajang akan menyebabkan rendahnya kesejahteraan subjektif. 
Pada kedua orang partisipan dalam penelitian ini, kondisi belum adanya pasangan menjadi sebuah permasalahan. Keduanya merasa bahwa tidak sama dengan teman seusia yang sudah menikah atau sedang merencanakan pernikahan. Mereka juga merasa tidak nyaman jika lingkungan menanyakan tentang tema pernikahan, bahkan dibandingkan dengan saudara seusianya yang sudah menikah. Mereka cenderung mengambil langkah membatasi interaksi dengan keluarga dan lingkungan untuk menghindari pertanyaan tentang pasangan atau pernikahan. Pada partisipan pertama tidak adanya pasangan bahkan sampai membuat ia memutuskan untuk menghabiskan waktu di dalam kamar. Bagi keduanya pergantian hari pun menjadi sebuah tekanan karena memikirkan usia yang semakin bertambah namun belum memiliki pasangan. Seringkali ketika malam pun mereka sangat mengkhawatirkan masalah ini dan membuat tidak bisa tidur, yang membuat keesokan harinya tidak fresh untuk melakukan kegiatan esok harinya. Setiap hari dilalui dengan mencemaskan tidak bisa mendapatkan pasangan, dan juga merasa tidak puas dengan pencapaian yang dimiliki saat ini. Bahkan pada partisipan pertama motivasi untuk melakukan kegiatan produktif pun sudah tidak ada.

Permasalahan yang dialami oleh kedua partisipan di atas juga memung- kinkan terjadi pada individu lainnya. Kondisi tersebut membuat para partisipan menjadi tidak nyaman dan mengganggu kehidupan sehari-hari sehingga perlu diberikan sebuah intervensi psikologis agar partisipan dapat bergerak ke dalam kondisi optimal. Intervensi psikologis saat ini terus berkembang, salah satunya adalah intervensi psikologis yang didasarkan pada pendekatan positive psychology, yaitu positive psychotherapy.

\section{Konsep Dasar Kesejahteraan Subjektif}

Kesejahteraan subjektif merupakan evaluasi kognitif dan afektif seseorang dari hidupnya. Evaluasi ini meliputi reaksi emosional terhadap peristiwa serta penilaian kognitif kepuasan dan pemenuhan. Dengan demikian, kesejahteraan subjektif adalah konsep global yang mencakup pengalaman emosi yang menyenangkan, rendahnya tingkat mood negatif, dan kepuasan hidup yang tinggi (Diener dkk, dalam Snyder \& Lopez, 2002).

Untuk memahami kesejahteraan subjektif, ada konsep-konsep dasar yang dapat dikategorikan menjadi tiga kelompok, yaitu: (1) need and goal satisfaction theories, (2) process or activity theories, dan (3) genetic and personality disposition theories. Konstelasi teori pertama terpusat sekitar gagasan bahwa reduksi ketegangan (misalnya eliminasi rasa sakit dan pemenuhan kebutuhan biologispsikologis) menimbulkan kebahagiaan. 
Prinsip kesenangan yang dikemukakan oleh Freud (1933/1976) dan model hirarki kebutuhan Maslow (1970) merupakan pendekatan ini. Omodei dan Wearing (1990) menemukan bahwa sejauh mana kebutuhan individu dapat dipenuhi berhubungan positif dengan tingkat kepuasan hidup mereka.

Goal theory berpendapat bahwa individu mencapai kesejahteraan subjektif ketika mereka bergerak menuju sebuah kondisi ideal atau mencapai tujuan yang berharga (standar). Peneliti lain telah memperluas ide ini untuk menggabungkan tingkat perbedaan dari standar perbandingan potensial lainnya. Michalos (1985) mendalilkan bahwa kebahagiaan berbanding terbalik dengan tingkat perbedaan dari beberapa standar, termasuk apa yang diinginkan, apa yang telah dimiliki di masa lalu, dan apa yang orang lain miliki secara relevan. Demikian juga, Higgins (1987) mengemukakan bahwa perbedaan dari satu "ideal self" dan "ought self" mengarah pada pengalaman emosi negatif. Teori need and goal satisfaction berpendapat bahwa pengurangan ketegangan dan pemuasan kebutuhan dan tujuan biologis - psikologis akan menyebabkan kebahagiaan.

Implikasi dari teori reduksi-ketegangan adalah bahwa kebahagiaan terjadi setelah kebutuhan dipenuhi dan sasaran yang diinginkan terpenuhi. Dengan kata lain, kebahagiaan adalah keadaan akhir ke arah mana semua aktivitas diarahkan pada tujuan yang diinginkan. Csikszentmihalyi (1975) menyarankan bahwa orang merasa paling bahagia ketika mereka terlibat dalam kegiatan menarik yang sesuai dengan tingkat keterampilan. la menyebut keadaan pikiran yang dihasilkan dari pencocokan ini tantangan dan keterampilan "flow", dan berpendapat bahwa orang yang sering mengalami flow cenderung sangat bahagia. Demikian pula, Cantor dan rekan-rekannya (Snyder dan Lopez, 2002) menekankan pentingnya partisipasi aktif dalam tugas-tugas kehidupan. Harlow dan Cantor (Snyder \& Lopez, 2002) menemukan bahwa partisipasi sosial merupakan prediktor kuat kepuasan hidup untuk orang tua pensiunan.

\section{Konsep Dasar Psikoterapi Positif}

Psikoterapi positif merupakan strategi terapi yang dilandasi oleh pendekatan transkultural, psikodinamika, dan cognitive-behavioral untuk membangun emosi positif, kekuatan karakter, dan kebermaknaan sebagai upaya mengatasi gangguan klinis maupun hal-hal negatif (Peseschkian 1987).

Psikoterapi positif memiliki gagasan membentuk happiness. Menurut Seligman dkk (2006), psikoterapi positif merupakan terapi yang terfokus pada upaya membentuk emosi positif, kekuatan karakter, dan kebermaknaan dengan cara 
membangun hidup yang menyenangkan (pleasant life), hidup yang mengikat pada aktivitas (enganged life), dan hidup yang bermakna (pursuit of meaning) untuk mengatasi gangguan klinis maupun hal-hal negatif.

Pertama: Pleasant Life. Kehidupan yang menyenangkan memiliki banyak emosi positif. Kehidupan yang menyenangkan menyangkut dengan kehidupan saat ini, masa lalu, dan masa depan. Emosi positif di masa lalu meliputi kepuasan, pemenuhan, kebanggaan dan ketenangan. Mengembangkan rasa syukur dan berlatih untuk memaafkan juga dapat meningkatkan emosi positif. Emosi positif mengenai masa depan meliputi harapan, optimisme, keyakinan, dan kepercayaan diri. Harapan dan optimis dapat mencegah munculnya depresi (Seligman, 2002). Untuk mengatasi hal ini, psikoterapi positif memodifikasi antara harapan dan optimisme untuk melawan kondisi pesimistik yang ada (Seligman, 2002; Synder 2000). Emosi positif mengenai masa sekarang meliputi kepuasan yang berasal dari kesenangan segera dan psikoterapi positif memberikan latihan untuk belajar menikmati pengalaman mendapatkan kesenangan segera (misalnya saja makan). Emosi yang lebih positif sering dikaitkan dengan rendahnya kemungkinan terjadi kecemasan ataupun depresi. Fredickson dan Branigan (2005) memberikan bukti penting dalam pene- litiannya bahwa emosi positif mengalahkan efek merugikan dari emosi negatif, yaitu pada fisiologi, perhatian dan kreativitas.

Kedua: Engaged Life. Happiness kedua dalam teori Seligman adalah engaged life, hidup yang mengejar keterlibatan, yaitu keterlibatan dan penyerapan dalam pekerjaan, hubungan intim dan rekreasi (Csikszentmihalyi, 1990). "Flow" adalah istilah dari Csikszentmihalyi untuk kondisi psikologis yang menyertai dalam keterlibatan pada suatu aktivitas. Perhatian benar - benar difokuskan pada kegiatan tersebut, rasa dalam diri hilang ketika memiliki "flow" (Moneta \& Csikszentmihalyi, 1996). Seligman (2002) mengusulkan bahwa salah satu cara untuk meningkatkan keterlibatan dan "flow" adalah mengidentifikasi bakat dan kekuatan tertinggi yang dimiliki individu dan kemudian membantu mencari peluang bagaimana kekuatan tersebut dapat digunakan. Patterson dan Seligman (2005) menyebut kekuatan tertinggi tersebut dengan istilah "signature strengths". Sebagai contoh, individu dengan "signature strength" dalam hal kreativitas akan didorong untuk menekuni bidang fotografi, seni patung, seni lukisan dan lain - lain.

Ketiga: Meaningful Life. Happiness yang ke-tiga dalam teori Seligman adalah mengejar makna hidup. Hal ini terdiri dari penggunaan "signature strengths" dan menyajikan sesuatu yang dipercaya lebih 
besar dari diri sendiri. Misalnya saja tergabung dalam institusi positif seperti institusi keagamaan, politik, keluarga, masyarakat dan bangsa. Institusi tersebut dijadikan sebagai sarana membentuk hidup yang bermakna dan menghasilkan rasa kepuasan serta keyakinan bahwa seseorang telah hidup dengan baik. Kondisi tersebut berkorelasi dengan terciptanya happiness.

Fredrickson (Magyar-Moe, 2009) mengatakan bahwa seseorang lebih baik berkonsentrasi pada kelebihan yang dimilikinya dibandingkan pada kekurangan yang dimiliki dan juga lebih baik berkonsentrasi pada kekuatan yang dimiliki dibandingkan dengan masalah yang sedang dihadapinya. Hal tersebutlah yang menjadi hal pokok dalam psikologi positif (positive psychology).

Clifton dan Nelson (Magyar-Moe, 2009) mengatakan bahwa akan lebih mendapatkan manfaat jika menggunakan kekuatan yang dimiliki seseorang dibandingkan jika melihat kelemahan dari klien yang dihadapi. Mengatasi masalah dengan fokus pada kelemahan yang terjadi menjadi lazim dilakukan. Clifton dan Nelson memaparkan mengenai kekeliruan hal tersebut. Kekeliruan pertama adalah terdapat pendapat bahwa mengatasi kelemahan juga merupakan sebuah cara untuk memperbaiki keadaan seseorang untuk lebih baik. Kekeliruan yang dimaksud dalam hal tersebut, yaitu mengurangi kelemahan seseorang tidak serta merta memunculkan kelebihan dari seseorang tersebut, namun paling tidak dapat membawa seseorang pada kondisi rata-rata. Kekeliruan kedua adalah adanya pendapat bahwa tidak perlu meningkatkan kekuatan seseorang dikarenakan hal tersebut merupakan sebuah proses alamiah yang akan berkembang dengan sendirinya. Pada dasarnya kekuatan dalam diri seseorang adalah dalam keadaan rata-rata atau normal saja, hingga kekuatan tersebut diasah untuk menjadi berkembang. Kekeliruan ketiga adalah adanya keyakinan bahwa kekuatan dan kelemahan merupakan sesuatu yang bertentangan yang artinya pada saat seseorang memiliki kelemahan tertentu, maka kelemahan tersebut dapat berubah menjadi suatu kekuatan pada seseorang tersebut. Hal tersebut salah, karena pada dasarnya saat melihat kekuatan seseorang tidak lagi melihat kelemahannya.

Strengthy theory ini kemudian dibawa ke dalam disiplin positive psychology. Seligman dan Steen (2005) mengusung suatu formula kebahagiaan yaitu saat seseorang menemukan kelebihan kelebihan (strength) dan kemudian menemukan cara untuk memanfaatkan kelebihan tersebut, maka akan membuat seseorang terlibat dalam suatu kehidupan (engaged with life).

Teori ini merupakan salah satu teori pokok dalam positive psychology. Pada teori ini dijelaskan dampak positif dari 
adanya emosi positif dalam kehidupan manusia. Fredrickson dan Branigan (2005) menyatakan bahwa hadirnya emosi positif dapat memberikan dampak positif pada banyak hal, bukan saja membuktikan bahwa kehidupan terbebas dari suatu masalah tetapi juga membantu dalam mengembangkan kehidupan. Salah satunya adalah munculnya kreativitas, menambahkan kemampuan dalam pemecahan masalah, memiliki pandangan yang lebih terbuka serta dapat berpikir fleksibel. Dipaparkan lebih lanjut bahwa seseorang yang berada dalam keadaan bahagia akan lebih mudah dalam melakukan apa yang ingin mereka lakukan, juga melakukan apa yang menjadi tanggung jawab mereka dalam sosial, serta apa yang harus diselesaikan. Individu akan lebih senang dan termotivasi untuk mencapai tujuan hidupnya, lebih mudah memperoleh informasi dan dapat berpikir lebih baik. Selain itu, sebagaimana disampaikan oleh Aspinwall dan Richer (1999), emosi positif dapat menuntun seseorang untuk tidak mudah menyerah dari setiap tugas dan akan memberikan performa yang terbaik pada setiap pekerjaan dan aktivitasnya.

The broaden and build theory of positive emotions ini terdiri dari beberapa jenis, yaitu the broaden hypothesis, the build hypothesis, the undoing hypothesis, the resilience hipothesis, dan the flourish hypothesis yang dijelaskan sebagai berikut. Pertama: The broaden hypothesis. Menurut Fredrickson (1998, 2001), saat seseorang merasakan emosi positif maka ia akan lebih mudah melihat banyak kemungkinan dihadapannya. Hal ini tentunya bertolak belakang dengan keadaan saat orang memiliki emosi negatif. Berdasarkan pendapat dari Frijda (1986), diketahui bahwa saat seseorang sedang mengalami emosi negatif, ruang pandangannya menjadi sempit dan kemudian berpengaruh dalam caranya mengambil keputusan.

Salah satu manfaat dari adanya emosi positif dalam diri seseorang adalah optimalisasi faktor kognitif mencakup pola berpikir. Aspek kognitif yang berfungsi optimal tersebut akan membuat seseorang berada pada keadaan di mana ia dapat melihat berbagai sumberdaya ataupun potensi yang ada di dalam dirinya (Fredrickson, dalam Magyar \& Moe, 2009).

Kedua: The build hypothesis. Sementara emosi positif dapat memperluas pola pikir dan tindakan seseorang, berbagai sumber daya yang ada dalam diri manusia juga dibangun dari waktu ke waktu. Sumber daya tersebut meliputi sumber daya fisik (koordinasi, kardiovaskuler, kesehatan, dan kekuatan otot), sumber daya sosial (persahabatan, ketrampilan sosial, dan dukungan), sumber daya intelektual (pengetahuan dan pemecahan 
masalah), sumber daya psikologis (optimism, kreativitas, dan ketahanan). Meskipun adanya emosi positif dapat meningkatan sumber daya tersebut dalam waktu sementara namun tetap dapat digunakan dalam situasi yang mendesak dan mengancam.

Ketiga: The undoing hypothesis. Dalam konsep untuk memperluas pikiran dan tindakan yang muncul sesaat serta meningkatkan sumber daya manusia yang lebih lama, dinyatakan bahwa emosi positif dapat meruntuhkan emosi negatif yang masih melekat di dalam diri manusia. Fredrickson memberi istilah pada gagasan ini sebagai undoing hypothesis. Gagasan dibalik konsep ini adalah bahwa serangkaian pikiran dan tindakan tidak dapat menyempit dan meluas secara serempak. Oleh karena itu, memasukan emosi positif pada situasi setelah diliputi emosi negatif dapat melepaskan cengkraman emosi negatif. Pada proses tersebut emosi positif semakin baik kualitasnya akan terlihat dengan kemampuan semakin luasnya pandangan dalam memandang apa yang terjadi di dunia. Efek dari undoing hypothesis dapat meliputi pada peningkatan fungsi kognitif dan juga fisiologis.

Hasil penelitian yang dilakukan oleh Fredrickson menyebutkan bahwa banyak manusia secara intuitif mengetahui bahwa emosi positif dapat memberikan efek undoing pada emosi negatif.
Dengan demikian setiap manusia dapat dibantu untuk dapat lebih memahami intuisi tersebut, sehingga dapat dapat memahami efek dari emosi positif saat emosi negatif sedang ada di dalam diri yang pada akhirnya dapat menajadi suatu kemampuan dalam mengatasi permasalahan dan lebih maju dalam menghadapi kehidupan.

Keempat: The resilience hypothesis. Konsep ini menetapkan bahwa keberadaan emosi positif dengan menggunakan konsep broadening dapat meningkatkan kondisi well being seseorang secara berkesinambungan (upward spiral) (Fredrickson, dalam Magyar-Moe, 2009). Gagasan ini bertolak belakang dengan konsep depresi yaitu downward spiral. Pada saat seseorang mengalami kondisi negatif dan kemudian diikuti dengan emosi negatif, maka akan diikuti dengan memiliki pandangan yang negatif terhadap kondisi tersebut dan pada akhirnya menimbulkan suatu kondisi pesimistik. Sebaliknya saat kondisi positif hadir, maka ia akan melihat berbagai kemungkinan atas kondisi yang dihadapi dan pada akhirnya memunculkan optimis. Dengan demikian seseorang yang terbiasa memiliki emosi positif akan mengalami peningkatan dalam well being. Kondisi well being yang baik pada diri seseorang akan membantu dalam kemampuan mengatasi masalah. Dapat disimpulkan bahwa emosi positif di dalam diri 
seseorang dapat membantu meningkatkan kemampuan memecahkan masalah dan lebih tangguh (resilien) atas kondisi yang dianggapnya sebagai suatu kemalangan.

Kelima: The flourish hypothesis. Keyes menyatakan bahwa maksud dari flourish dibutuhkan agar seseorang dapat lebih hidup optimal dan dapat merasakan pengalaman yang baik dalam hidup seperti lebih berkembang secara personal, tangguh dan lebih meningkat. Flourish hypothesis menyatakan bahwa kunci dari perkembangan pada manusia adalah perbandingan antara adanya emosi positif dan emosi negatif (Fredrickson \& Losada, dalam Magyar-Moe, 2009). Lebih jelasnya lagi disebutkan bahwa jika di dalam kehidupan lebih didominasi oleh emosi negatif maka akan menghambat proses berlangsungnya kehidupan yang lebih baik.

\section{Positive Psychotherapy dan Subjective Well Being}

Psikoterapi positif merupakan terapi yang terfokus pada upaya untuk membentuk emosi positif, kekuatan karakter dan kebermaknaan dengan cara membangun hidup yang menyenangkan (pleasant life), hidup yang penuh aktifitas (enganged life) dan hidup yang bermakna (pursuit of meaning) untuk mengatasi gangguan klinis maupun hal-hal negatif yang bisa dilakukan secara individual maupun kelompok (Peseschkian, 1998).
Seligman dkk (2006) mengemukakan pendapat bahwa dalam rentang waktu 100 tahun terakhir, psikoterapi selalu berfokus pada proses memperbaiki aspek negatif dari indivdu seperti trauma, kekurangan, dan simtom dari gangguan. Penekanan terhadap masalah yang dihadapi individu, membuat psikologi berperan dengan baik dalam memperbaiki kondisi gangguan, namun di sisi lain justru sedikit pencapaian dalam mengembangkan sisi positif dari manusia. Psikoterapi positif dikembangkan melalui penelitian-penelitian untuk mengatasi depresi. Psikoterapi positif memiliki hipotesis bahwa depresi dapat diatasi secara efektif tidak hanya dengan mereduksi simtomsimtomnya yang bersifat negatif, namun juga dengan menumbuhkan emosi positif, kekuatan karakter dan kebermaknaan hidup. Terbentuknya emosi positif, kekuatan karakter dan kebermaknaan hidup diasumsikan akan membantu partisipan dalam menanggapi permasaahan yang dihadapi saat ini.

\section{METODE}

\section{Desain Penelitian}

Penelitian ini bertujuan untuk mengetahui keberhasilan dari pemberian intervensi psikologis berupa psikoterapi positif untuk membantu meningkatkan kondisi kesejahteraan subjektif wanita dewasa awal yang belum memiliki 
pasangan. Proses untuk memahami fenomena kesejahteraan subjektif membutuhkan pendekatan individual dalam artian dibutuhkan pemahaman kasus per kasus karena konsep kesejahteraan subjektif seseorang sangat bergantung pada pribadi orang masing-masing.

Penelitian ini menggunakan rancangan eksperimen quasi dengan jumlah partisipan terbatas, dengan menelaah perbedaan hasil terapi sebelum dan sesudah terapi diberikan pada partisipan yang sama.

\section{Subjek Penelitian}

Secara umum studi kasus menggunakan satu atau lebih partisipan. Suatu penelitian studi kasus mendeskripsikan etiologi, perkembangan atau gejala dari gangguan yang dialami individu, metode yang digunakan untuk memahami dan menanggulangi gejala, serta bukti dari efektivitas dari perlakuan yang diberikan. Untuk mendapatkan partisipan dalam penelitian ini digunakan teknik purposive sampling, yaitu sebuah strategi untuk menentukan partisipan yang berdasarkan pada criteria untuk menjawab pertanyaan penelitian (Barker, Pistrang, \& Elliot, 2002). Adapun kriteria partisipan dalam penelitian ini adalah sebagai berikut: (1) Wanita dewasa awal dengan usia diatas rata-rata usia menikah di Indonesia, yaitu di atas usia 24 tahun (Riskesdas, 2010), (2) Belum memiliki pasangan (suami atau pacar), (3) Memiliki keinginan untuk segera menikah, (4) Dorongan dan pertanyaan dari keluarga mengenai pasangan dipersepsikan sebagai sebuah tekanan, (5) Skor kepuasan hidup berada di kategori rendah, atau setidaknya di kategori sedang, (6) Skor positif afek berada di kategori rendah, atau setidaknya di kategori sedang, (7) Skor negative afek berada pada kategori tinggi, atau setidaknya di kategori sedang.

Pada proses penjaringan partisipan, peneliti sempat menemui delapan kandidat yang memenuhi kriteria partisipan penelitian yang telah ditentukan, namun dari kedelapan orang yang sudah diwawancarai awal, hanya dua orang yang bersedia untuk melanjutkan sampai tahap pemberian terapi.

\section{Metode Pengumpulan Data}

Data dengan metode penelitian ini diperoleh melalui penggunaan skala pengukuran psikologi. Untuk melihat kepuasan hidup, alat ukur yang digunakan berdasarkan konsep Diener (2005) menggunakan skala Satisfaction With Life Scale (SWLS) berupa 5 item mengenai kepuasan hidup dengan skala ordinal 1-7 untuk penilaian partisipan bagi masingmasing item, yang dibuat untuk mengetahui level kepuasan hidup. Selain itu digunakan pula alat ukur berdasarkan teori Watson (1988) yang berupa kuesioner Positive Affect and Negative 
Affect Schedule (PANAS) untuk mengukur kebahagiaan yang terdiri atas 20 item mengenai afek positif dan afek negatif, serta menggunakan skala ordinal 1-5 untuk penilaian partisipan bagi masingmasing item. Alat ukur yang semula berbahasa Inggris ini dimodifikasi oleh Mustikawati (2014) dengan diujicobakan pada 62 responden dengan hasil cronbach alpha 0,843 untuk alat ukur Satisfaction With Life Scale (SWLS); serta 0,862 untuk item-item positive affect, dan 0,838 untuk item-item negative affect pada alat ukur Positive Affect and Negative Affect Schedule (PANAS). Validitas item pada kuesioner diperiksa melalui expert judgement, yakni pembimbing pada penelitian ini yang memiliki kualifikasi baik pada bidangnya, yakni sebagai Psikolog dan Psikoterapis. Aspek yang diobservasi adalah aspek-aspek komunikasi antara partisipan dan peneliti terutama aspek nonverbal dan interview terkait aspek-aspek kesejahteraan subjektif dan afek, guna memperdalam dan memperkaya kualitas hasil kuesioner yang diukur.

\section{Prosedur Intervensi}

Prosedur intervensi didasarkan pada teori Rashid (2013) yang berlangsung selama 14 (empat belas sesi) kemudian dilakukan modifikasi. Sesi yang dijalankan menjadi 6 (enam) sesi dengan tetap bertujuan pada peningkatan kesejahtera- an subjektif dan perbaikan kualitas afek. Rashid (2013) mengutarakan bahwa banyaknya sesi terapi, tugas yang diberikan, dan fokus bahasan pada tiap sesi harus dirancang untuk memenuhi kebutuhan klien. Berdasarkan penelitian yang telah dilaporkan Wardati (2014), dari 14 sesi terapi yang dijalankan, tujuh sesi awal memberikan dampak peningkatan signifikan, sedangkan sisanya tidak terlalu memberikan peningkatan yang signifikan, sehingga disimpulkan bahwa tujuh sesi akhir berfungsi sebagai monitoring dan menguatkan perubahan yang telah tercapai pada tujuh sesi awal. Berdasarkan pendapat tersebut, peneliti kemudian menyusun enam sesi terapi yang akan dijalankan, dengan mempertimbangkan ada beberapa aktivitas terapi yang bias dileburkan dalam satu sesi. Sesi inti yang terdiri dari introduksi dan terminasi dengan pengenalan diri yang berupa kekuatan dan aspek positif tetap diberikan dengan upaya peningkatan kebahagiaan dan sudut pandang kebersyukuran yang dari diskusi peneliti dan supervisor, penting untuk tetap diberikan/diselenggarakan.

Secara singkat, isi dari masingmasing sesi dapat diuraikan sebagai berikut: (1) Sesi1 berisi orientasi, kontrak dan inform consent serta prates dan positive introduction story, (2) Sesi 2 berisi engagement, yaitu mengidentifikasi kekuatan dan menggunakannya dalam perencana- 
an kegiatan dan pengembangan rasa syukur (Gratitude), (3) Sesi 3, yaitu Pleasure and Pleasant Life - termasuk di dalamnya melepaskan emosi negatif dan mempelajari teknik forgiveness, (4) Sesi 4, yaitu Meaningful Life - member makna dan mencanangkan pencapaian keberartian hidup, guna menjadikan hidup lebih bernilai, (5) Sesi 5, yaitu Aktif-Konstruktif memanfaatkan pemahaman tentang kekuatan diri untuk mengubah pendekatan dan perilaku sehingga mengarah pada pencapaian subjek di luar masalah yang tengah dialami, (6) Sesi 6, yaitu Integrasi dan Evaluasi Terapi dan Pascates.

\section{Teknik Analisis Data}

Analisis data penelitian dilakukan secara kuantitatif dan kualitatif. Teknik analisis yang digunakan untuk menguji hipotesis dalam penelitian ini adalah teknik analisis statistika paired sample $t$ - test untuk melihat subjective well being sebelum dan sesudah diberikan postive psychotherapy. Pada penelitian ini dilakukan pengukuran dengan menggunakan alat ukur Satisfaction With Life Scale (SWLS) untuk mengetahui level kepuasan hidup dan juga Positif Affect and Negative Affect Schedule (PANAS) untuk mengukur kemunculan afek positif - negatif kedua partisipan. Pengukuran dilakukan sebelum dan sesudah rangkaian terapi diberikan seluruhnya. Berdasarkan pengukuran tersebut data akan dipaparkan dengan diagram batang. Untuk memahami kondisi kepuasan hidup dan kemunculan afek positif - negatif berserta perubahannya akan dijelaskan dengan metode deskriptif. Adapun norma yang digunakan untuk mendeskripsikan kondisi kepuasan hidup dan positif - negatif afek adalah norma kelompok yang dibagi menjadi 3 kategori, sebagai berikut:

\section{Tabel 1. Kategori Pengelompokan Level Kepuasan Hidup}

\begin{tabular}{lll}
\hline No. & Skor & Kategori \\
\hline 1. & $5-15$ & Rendah \\
2. & $16-25$ & Sedang \\
3. & $26-35$ & Tinggi
\end{tabular}

Tabel 2. Kategori Pengelompokan Level Positif - Negatif Afek

\begin{tabular}{lll}
\hline No. & Skor & Kategori \\
\hline 1. & $10-30$ & Rendah \\
2. & $31-50$ & Sedang \\
3. & $51-70$ & Tinggi \\
\hline
\end{tabular}


Metode pengolahan data berikutnya adalah dengan menggunakan pendekatan kualitatif. Metode kualitatif ini digunakan untuk memahami proses yang terjadi dalam diri individu atas pemberian tiap sesi terapi. Data yang digunakan untuk membahas perubahan kondisi kesejahteraan subjektif setiap partisipan adalah melalui worksheet terapi, wawancara, dan juga proses diskusi yang berjalan dari setiap sesi terapi. Penarikan kesimpulan terhadap data kualitatif akan mengacu pada dua sumber teori, yaitu kesejahteraan subjektif yang dikemukakan Diener dan juga teori-terori dasar tentang psikoterapi positif yang dirancang oleh Rashid (2008).

\section{HASIL PENELITIAN}

Berdasarkan Pengukuran, maka didapat kondisi prates dan pascates dari kedua partisian, sebagai berikut:

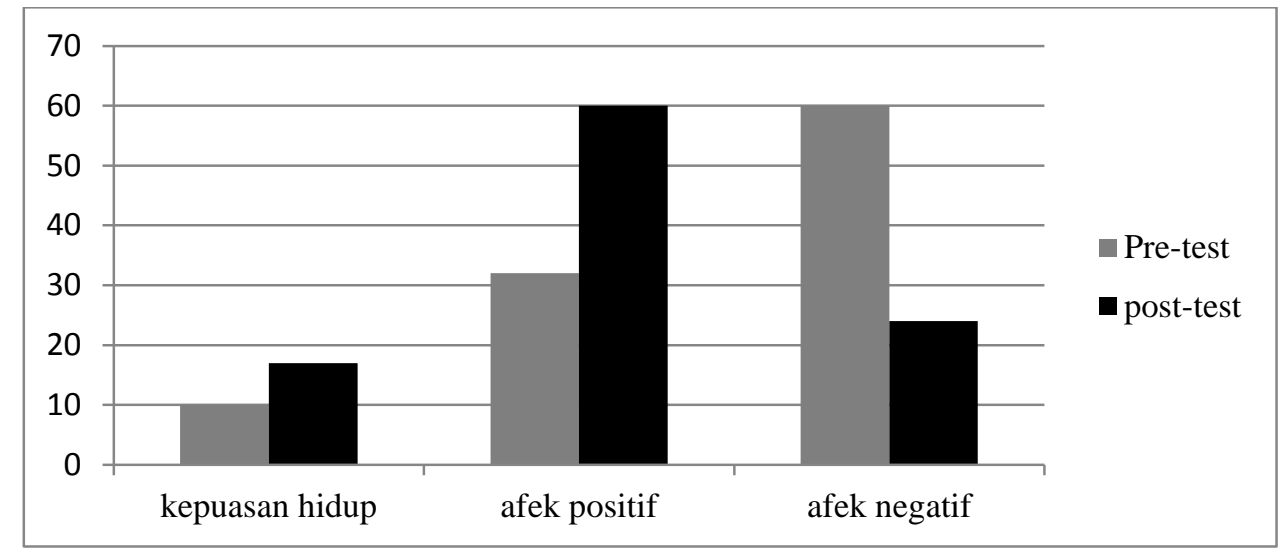

Grafik 1. Prates - Pascates Partisipan 1

Berdasarkan pengukuran yang dilakukan, diketahui bahwa partisipan 1 memiliki skor kepuasan hidup sebesar 10 poin (kategori rendah), skor positif afek sebesar 32 poin (kategori sedang), dan skor negatif afek sebesar 60 poin (kategori tinggi).

Setelah diberikan psikoterapi positif sebanyak 6 sesi, terlihat peningkatan dalam skor kepuasan hidup sebanyak 7 poin (kategori sedang), peningkatan 28 poin pada positif afek (kategori tinggi), dan penurunan sebanyak 36 poin pada negatif afek (kategori rendah). Berdasarkan grafik perubahan skor tersebut, terlihat bahwa psikoterapi positif memberikan pengaruh terhadap peningkatan kepuasan hidup, peningkatan positif afek dan penurunan negatif afek. 


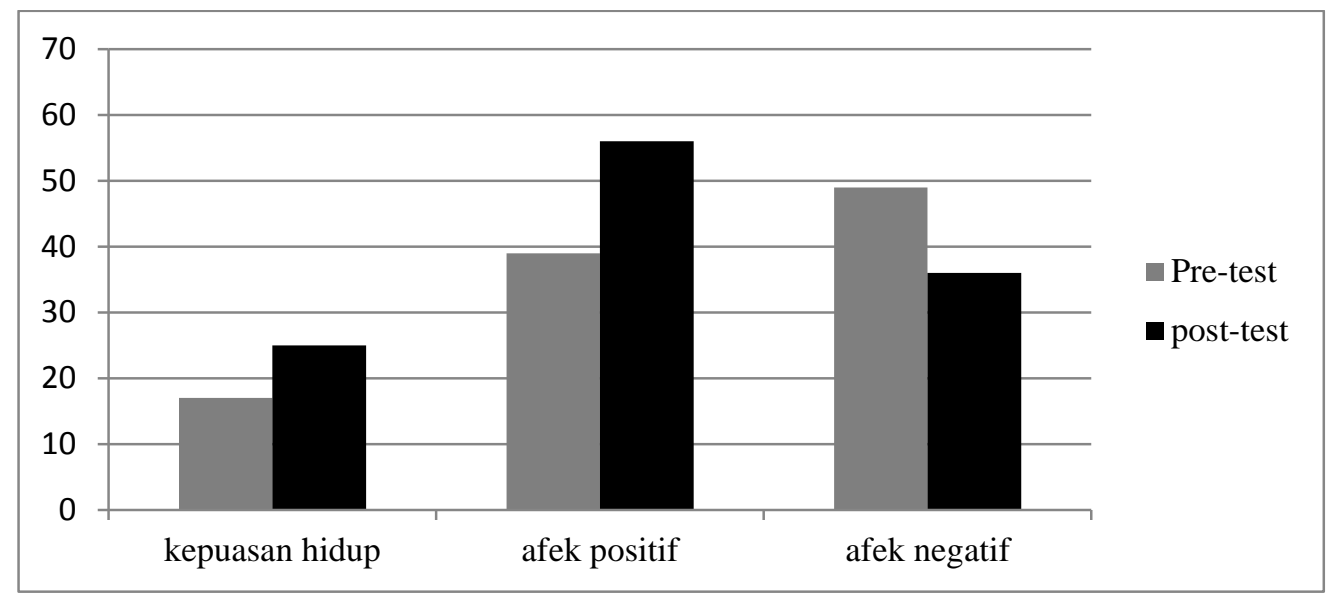

Grafik 2. Prates - Pascates Partisipan 2

Berdasarkan pengukuran yang dilakukan, diketahui bahwa partisipan 2 memiliki skor kepuasan hidup sebesar 17 poin (kategori sedang), skor positif afek sebesar 39 poin (kategori sedang), dan skor negatif afek sebesar 49 poin (kategori tinggi).

Setelah diberikan psikoterapi positif sebanyak 6 sesi, terlihat peningkatan dalam skor kepuasan hidup sebanyak 12 poin (menjadi kategori tinggi), peningkatan 17 poin pada positif afek (menjadi kategori tinggi), dan penurunan sebanyak 11 poin pada negatif afek (kategori sedang). Berdasarkan grafik perubahan skor tersebut, terlihat bahwa psikoterapi positif memberikan pengaruh terhadap peningkatan kepuasan hidup, peningkatan positif afek dan penurunan negatif afek.

\section{PEMBAHASAN}

Upaya pembentukan pleasant life, di antaranya dilakukan dengan cara mengarahkan wanita dewasa awal yang belum memiliki pasangan untuk mendata hal-hal yang menjadi berkah dalam kehidupannya, terlepas dari pengalaman negatif yang dialami saat ini. Hal tersebut mengarahkan pikiran untuk mengingat hal-hal positif yang ditujukan untuk membentuk emosi positif dalam diri. Pembentukan emosi positif menjadi penting dalam pendekatan terapi ini didasarkan pada the broaden and build hypothesis. Saat emosi positif terbentuk, maka cara pandang akan menjadi lebih luas, bisa melihat berbagai macam kemungkinan yang dapat dilakukan untuk mengatasi masalah, memunculkan sumber energi 
dalam diri, dan lebih resilient dalam menghadapi masalah.

Pada penelitian ini, kedua partisipan diarahkan untuk mengingat dan mensyukuri keberkahan yang pernah dialami di masa lalu dan juga yang dialami setiap hari mulai dari hal terkecil sekali pun. Rasa syukur yang timbul atas kesadaran berkah yang dialami dalam hidupnya menguatkan emosi positif yang dibangun dalam sesi terapi. Upaya mengarahkan fokus pada keberkahan yang dialami juga memberikan kesempatan untuk evaluasi ulang terhadap kehidupan, bahwa anggapan kehidupannya negatif karena belum memiliki pasangan hidup merupakan sebuah kekeliruan. Upaya pembentukan pleasant life dengan cara bersyukur dan aktivitas berterima kasih juga memberikan kesempatan bagi para partisipan untuk melihat kembali bahwa mereka masih memiliki orang-orang yang memberikan dukungan dan kasih sayang. Kesadaran akan keberkahan hidup lainnya yang ia terima dan juga adanya dukungan orang-orang disekitarnya lewat aktivitas bersyukur dan berterima kasih mempertahankan kemunculan afek positif pada partisipan dan membuat mereka lebih bahagia dan termotivasi dalam menjalani hidup secara lebih baik.

Pembentukan engaged life dilakukan dengan mendorong partisipan untuk mengidentifikasikan kekuatan yang dimilikinya melalui peristiwa bahagia yang pernah mereka alami. Kondisi aktual saat sebelum menjalani terapi membentuk penilaian sebagai diri yang tidak memiliki keunggulan dan tidak seperti orang lain yang sudah sukses dalam hal pernikahan maupun pekerjaan. Melalui identifikasi terhadap pengalaman positif terdahulu para partisipan mampu mengenali hal-hal yang menjadi kekuaran dirinya. Pembentukan engaged life kemudian dicapai dengan cara mendorong para partisipan untuk mengembangkan kekuatannya melalui kegiatan nyata di keseharian. Melalui aktivitas pengembangan kekuatan, partisipan lebih meyakini bahwa mereka memiliki kekuatan untuk membuat hidup mereka lebih baik, mejalani kegiatan sehari-hari secara lebih menyenangkan dan mulai menjalankan kembali relasi dengan teman-teman yang sebelumnya mereka batasi. Selain menguatkan keyakinan bahwa mereka memiliki kekuatan yang bisa digunakan untuk mengatasi masalah, aktivitas dengan menggunakan kekuatan diri juga memberikan peluang untuk mendapat penilaian maupun respon positif dari orang lain. Hal tersebut berguna pula untuk memunculkan dan mempertahankan penghayatan afek positif. Melalui upaya pembentukan engaged life, partisipan tidak lagi memandang skeptis terhadap lingkungan yang sebelumnya mereka berpikir negatif bahwa lingkungan selalu merecoki mereka dengan tema pasangan atau perni- 
kahan. Timbulnya afek positif saat menggunakan kekuatan juga membuat mereka termotivasi untuk terus mengembangkan kekuatan diri dan juga menjalankan aktivitas yang bisa membuat mereka lebih bahagia dan menikmati hidup.

Upaya pembentukan meaning full life bertujuan agar partisipan mampu mencapai kebahagiaan hidup tidak hanya dari sisi pribadi, namun dengan pencapaian dalam ruang lingkup yang lebih luas. Hal ini dapat dicapai misalnya melalui relasi interpersonal, institusi pekerjaan, dan lain-lain. Hal tersebut memiliki makna bahwa kebahagiaan dalam hidup bukanlah berdasarkan kesenangan pribadi yang bersifat hedonis, namun juga dengan melibatkan aspek sosial. Pembelajaran dalam upaya pembentukan meaning full life adalah dengan mengelola cara mendapatkan kepuasan hidup. Pendekatan terapi ini membagi cara mencapai kepuasan menjadi dua kategori, yaitu maximizing dan satisficing. Kecenderungan manusia dalam mencapai kepuasan menurut terapi ini adalah dengan cara maximizing, yaitu berusaha mendapatkan kepuasan tertinggi dengan mencapai banyak hal yang dinilai menyenangkan. Cara tersebut dipandang kurang tepat karena cenderung tidak fokus, mengikuti ambisi pribadi yang kadang kala tidak realistis, mengembangkan sifat tidak pernah puas dan memungkinkan timbulnya rasa frustrasi atau kelelahan psikofisik.
Psikoterapi positif berusaha mengarahkan partisipan untuk mencapai kepuasan dengan cara satisficing, yaitu dengan cara yang lebih realistis, terfokus, terencana dan memiliki penghayatan kepuasan terhadap aktivitas yang sedang dijalani. Pada kedua partisipan menyadari bahwa sebelumnya mereka cenderung tidak fokus terhadap apa yang mereka ingin capai, karena terpengaruh juga dengan pencapaian orang lain, bahkan mereka cenderung ingin mendapatkan pasangan atau pekerjaan namun tidak melakukan langkah apapun. Melalui satisficing, mereka mulai mampu mengarahkan fokus prioritas pencapaian dan juga langkah-langkah konkrit yang dapat mereka lakukan. Langkah berikutnya dalam pembentukan meaning full life adalah mengembangkan love and attachment dalam relasi interpersonal dengan menggunakan respon aktif-konstruktif. Pada sesi terapi ini, para partisipan menyadari bahwa mereka sering kali memberikan respon yang destruktif pada orang lain, bahkan ketika ada lawan jenis yang mendekati pun mereka cenderung memberikan respon yang destruktif. Melalui latihan mengidentifikasi tipe-tipe respon, para partisipan memahami bahwa dalam relasi interpersonal perlu juga memperhatikan perasaan orang lain, bahwa afek menyenangkan pun perlu dirasakan bersama, tidak hanya mengikuti emosi pribadi. Dengan teknik ini, para partisipan 
tidak lagi memberikan respon kesal atau marah kepada orang yang menanyakan tentang pasangan atau pernikahan dan lebih terbuka pada lawan jenis yang mendekati.

Berdasarkan hasil pengukuran, ada sedikit perbedaan dalam kadar perubahan yang dialami oleh kedua partisipan. Berkaitan dengan hal tersebut, peneliti mencoba menganalisis melalui proses tiap pertisipan merespon sesi terapi yang telah dilalui. Perbedaan pertama adalah dalam proses menemukan sisi positif diri. Pada partisipan dua ada nilai subjektif yang menghambat dalam menemukan hal positif diri, yaitu pemahaman bahwa menceritakan kebaikan yang dilakukan merupakan sebuah kesombongan. Hal tersebut juga menghambat partisipan dua dalam mengevaluasi keberkahan hidup yang terjadi dalam aktivitas bersyukur, berbeda dengan partisipan 1 yang lebih bisa mengeksplorasi sisi positif diri yang membuatnya mengalami keberkahan hidup untuk kemudian mengoptimalkannya.

Perbedaan selanjutnya adalah dalam mempelajari dan mengaplikasikan kesediaan untuk memaafkan dalam usaha untuk menetralkan afek negatif yang dialami sehari-hari. Partisipan dua masih cenderung memiliki cara pandang ingin seperti orang lain yang bisa lebih bersabar dari pada mengarahkan fokus untuk melatih kesediaan memaafkan. Pola berfikir “ingin menjadi seperti orang lain yang penyabar" justru menimbulkan respon rasa iri dalam diri partisipan terhadap orang lain, dari pada usaha konkrit dalam melatih cara memaafkan kejadian positif. Hal ini membuat afek negatif masih memberikan sedikit pengaruh dalam keseharian partisipan walaupun kadarnya sudah lebih menurun jika dibandingkan dengan kondisi sebelum menjalankan terapi. Berbeda dengan partisipan 1 yang lebih bisa mengaplikasikan kesediaan dalam memaafkan sehingga lebih bisa menetralisasi afek negatif yang muncul. Hal konkritnya adalah ketika partisipan menyelesaikan konflik relasi dengan temannya. Dengan mengaplikasikan teknik memaafkan partisipan bisa menetralisasi perasaan kesalnya, sehingga partisipan pertama lebih tenang untuk bertemu temannya dan menyelesaikan masalah, sedangakan sebelumnya partisipan pertama cenderung memberikan respon menjauh dari teman yang sedang berkonflik dengannya.

Perbedaan peningkatan juga terlihat dalam skor akhir kepuasan hidup. Partisipan pertama menilai kepuasan hidup diri berdasarkan pencapaian yang ia miliki. Kondisi pencapaian aktual pertisipan pertama saat pengukuran di akhir sesi terapi memang belum terdapat perubahan, namun perbedaan terlihat dari cara partisipan merespon kondisi aktualnya. Sebelumnya partisipan pertama cende- 
rung menyalahkan diri dan memandang diri negatif terakiat kondisinya sekarang, namun saat ini dalam diri partisipan muncul motivasi dan usaha konkrit untuk mencapai apa yang ia inginkan. Berbeda pada kondisi partisipan kedua yang sudah memiliki pekerjaan tetap, sehingga ada kondisi yang bisa ia nilai sebagai pencapaian hidup. Walaupun sebelumnya ia cenderung memandang negatif tentang pekerjaannya, melalui kegiatan gratitude dan memaksimalkan kekuatan diri di pekerjaannya mampu meningkatkan rasa puas dan bangga terkait pekerjaannya sekarang.

\section{SIMPULAN DAN SARAN}

Berdasarkan hasil data dan pembahasan, maka dapat ditarik beberapa simpulan sebagai berikut. Pertama: Psikoterapi positif mampu meningkatkan kondisi kesejahteraan subjektif wanita dewasa awal yang belum memiliki pasangan. Pada kondisi realita yang tetap sama (belum memiliki pasangan), sesi-sesi terapi yang dijalani mampu mengubah cara pandang kedua partisipan terhadap kehidupannya secara keseluruhan, meningkatkan penilaian kepuasan hidup, meningkatkan afek positif, dan menurunkan afek negatif yang selama ini mengganggu, sehingga kedua partisipan dapat menjalankan kehidupannya dengan lebih bahagia dan menjalankan peran dalam kehidupan sosial secara optimal.

Kedua: Sesi-sesi yang berisi pembentukan pleasant life berhasil menumbuhkan emosi positif pada diri para partisipan. Dalam hal ini the broaden and build hypothesis akan kegunaan emosi positif terbukti mampu membuat kedua partisipan menghadapi masalah secara lebih baik. Saat emosi positif tumbuh mereka dapat melihat kondisi saat ini sebagai sebuah proses yang harus dijalani untuk mencapai goals, bukan lagi sebuah kegagalan, memiliki energi dan motivasi untuk menjalankan aktivitas secara menyenangkan.

Ketiga: Pembentukan engaged life dan meaningfull life dapat membantu kedua partisipan untuk bisa terikat dengan aktivitas mereka saat ini, melakukan upaya pengembangan diri, memiliki kesediaan untuk menjalankan relasi sosial secara lebih terbuka, aktif dan menciptakan relasi yang bahagia.

Keempat: Secara keseluruhan penelitian ini membuktikan bahwa untuk menolong partisipan lepas dari masalah ataupun gangguan klinisnya tidak harus selalu berorientasi pada memperbaiki aspek psikologis yang bermasalah, namun dengan berfokus pada aspek kekuatan yang dimiliki pastisipan dan juga menumbuhkan emosi positif bisa membuat partisipan mampu menumbuhkan sendiri kebahagiaan dalam hidup mereka. 


\section{DAFTAR PUSTAKA}

Aspinwall, L.G. \& Richter, L. (1999). Optimism and self-mastery predict more rapid disengagement from unsolvable tasks in the presence of alternatives. Motivation and Emotion, 23 (3), 221-245.

Barker, C., Pistrang, N., \& Elliott, R. 2002. Research methods in clinical and psychology : an introduction for students and practitioners, 2, John Wiley \& Sons, Ltd. England

Csikszentmihalyi, M. (1975). Beyond boredom and anxiety. San Fransisco: Josey Bass Publishers.

Diener, E., Lucas, R., \& Oishi, R. (2005). The satisfaction with life scale. Journal of Personality Assessment, 49, 71-75.

Fredrickson, B.L. (1998). What good are positive emotions? rev gen psychol. 2(3), 300-319.

Fredrickson, B.L. (2001). The role of positive emotions in positive psychology. The broaden-and-build theory of positive emotions. Am Psychol. 56(3), 218-26.

Fredrickson, B.L. \& Branigan, C. (2005). Positive emotions broaden the scope of attention and thought-action repertoires. Cogn Emot. 19(3): $313-$ 332. doi: $10.1080 / 0269993044100023$

8.

Frijda, N.H. (1986). The emotions. Cambridge: Cambridge University Press.

Hanugraheni, A. Y., Nu'man, T.M. (2008). Naskah publikasi hubungan harapan sosial untuk menikah muda dengan stres pada wanita lajang suku jawa usia dewasa muda. Skripsi. Yogyakarta : UII.

Higgins, E.T., (1987). Self-discrepancy : a theory relating self and affect, APA, Inc.-Psychological Review 94 (3)

Kementrian Kesehatan RI. (2010). Riset kesehatan dasar-riskesdas, www.scribd.com/doc/52186303/RI SKESDAS-2010, diunduh 28 Juli 2014

Magyar-Moe, J.L. (2009). Therapist's guide to positive psychological intervention. New York : Academic Press.

Michalos, A. C. (1985). Multiple discrepancies theory (MDT). Social Indicators Research, 16, 347-413.

Moneta G.B. \& Csikszentmihalyi, M. (1996). The effect of perceived challenges and skills on the quality of subjective experience. Journal of Personality, 64(2), 275-310.

Mustikawati, F. (2014). Pengaruh happiness program terhadap tingkat 
happiness pada penyintas kanker payudara. Tesis. Jatinangor: Program Psikologi Profesi UNPAD.

Oishi, S., Schimmack, U., Diener, E., \& Suh, E. M. (1998). The measurement of values andindividualismcollectivism. Personality and Social Psychology Bulletin, 24, 11771189.

Omodei, M.M., Wearing, A.J. (1990). Need satisfaction and involvement in personal projects: toward an integrative model of subjective well-being, Journal of Personality and Social Psychology, 59 (4), 762769 .

Pavot, W. \& Diener, E. (1993). Review of the satisfaction with life scale. Journal o Psychological Assessment, 5 (2), 164-172.

Peseschkian, N. (1987), Positive psychotherapy: Theory and practice of a new method. Translated by Robert Walker. Berlin : Springer-Verlag.

Rashid,T. (2008), Positive psychotherapy, www.tayyabrashid.com/pdf/ppt.pdf , diunduh 28 Juli 2014.

Rashid, T. (2008), Positive psychotherapy: session by session planning, www.tayyabrashid.com/site/page ?view $=$ ppt, diunduh 2 Februari 2015.
Robinson, O. (2008). Developmental crisis in early adulthood: a composite qualitative analysis. London: Universityof London

Seligman, M. E. P. (2002).Authentic happiness. New York: Free Press.

Seligman, M. E. P. \& Steen, T. (2005). Making people happier: a randomized controlled study of exercises that build positive emotion, engagement, and meaning. Am. Psychol. (Submitted.)

Seligman, M. E.P. 2006. Learned optimism: how to change your mind and your life. New York: Pocket Books.

Seligman, M. E. P., Rashid, T., \& Parks, A. C. (2006). Positive psychotherapy. American Psychologist, 61, 774788.

Snyder, C.R. \& Shane J. L. (2002). Handbook of positive psychology. New York : Oxford University Press.

Wardati, M.A. (2014). Pengaruh Positive psychotherapy terhadap self esteem remaja korban kdrt. Tesis. Bandung : UNISBA.

Watson, D. \& Clark, L.A. (1988). Development and validation of brief measures of positive and negative affect: The PANAS Scales. Journal of Personality and Social Psychology, 54 (6), 1063-1070. 
Catur Pamungkas, Nurul Wardhani, \& Ahmad Gimmy Prathama Siswadi 